\title{
Długookresowe wahania przepływów rocznych głównych rzek w Polsce i ich związek z cyrkulacją termohalinową Atlantyku Północnego
}

\author{
Long-term fluctuations of annual discharges of the main rivers in Poland \\ and their association with the Northern Atlantic Thermohaline Circulation
}

\author{
ANDRZEJ A. MARSZ \\ Polskie Towarzystwo Geofizyczne, Oddział Bałtycki, \\ 81-342 Gdynia, ul. Waszyngtona 42; aamarsz@am.gdynia.pl
}

\author{
ANNA STYSZYŃSKA \\ Katedra Urbanistyki i Planowania Regionalnego, Politechnika Gdańska \\ 80-233 Gdańsk, ul. G. Narutowicza 11/12; astys19@wp.pl \\ WIESŁAWA E. KRAWCZYK \\ Wydział Nauk o Ziemi, Uniwersytet Śląski, \\ 41-200 Sosnowiec, ul. Będzińska 60; wieslawa.krawczyk@us.edu.pl
}

Zarys treści. Praca dotyczy przyczyn występowania multidekadowej zmienności średnich rocznych przepływów największych rzek Polski (Wisła, Bug, Odra, Warta). Taka zmienność powoduje, że w wieloletnich przebiegach przepływów rocznych zaznaczają się zmiany znaków trendów (z dodatnich na ujemne i odwrotnie). Przyczyną jest długookresowa zmienność składowej powierzchniowej cyrkulacji termohalinowej na północnym Atlantyku (NA THC - Northern Atlantic Thermohaline Circulation), która, poprzez wymuszanie zmian charakteru cyrkulacji atmosferycznej, reguluje zmienność temperatury powietrza nad Europą Środkową. Podczas występowania dodatnich faz NA THC przepływy roczne rzek maleją, zmniejsza się również zakres zmienności międzyrocznej oraz rośnie prawdopodobieństwo wystąpienia przepływów niskich. W okresie ujemnych faz NA THC przepływy rosną i rośnie zakres ich zmienności. Przeciętne różnice przepływów rocznych między okresami z występowaniem dodatnich a ujemnych faz NA THC wynoszą około 10\%. Wzrost temperatury powietrza w czasie dodatnich faz NA THC, silny zwłaszcza w kwietniu, lipcu i sierpniu, powoduje wzrost ewapotranspiracji w zlewniach, co zmniejsza wartości odpływu. Nie można wykluczyć, że zmienność NA THC w znaczącym stopniu wpływa również na częstość występowania susz w Polsce.

Słowa kluczowe: przepływy roczne rzek, zmienność multidekadowa, Polska, cyrkulacja termohalinowa, Atlantyk Północny. 


\section{Sformułowanie zagadnienia, cel pracy}

Składową powierzchniową cyrkulacji termohalinowej na Atlantyku Północnym (dalej NA THC - Northern Atlantic Thermohaline Circulation), stanowiącą fragment globalnego „przenośnika taśmowego” cyrkulacji termohalinowej (Broecker, 1991), charakteryzuje zmienne natężenie. W okresach wzrostu natężenia NA THC rośnie transport ciepła i soli wraz z wodami ze strefy tropikalnej do wyższych szerokości Atlantyku Północnego. W rezultacie zmienności natężenia NA THC dochodzi do rytmicznych, długookresowych zmian zasobów ciepła w powierzchniowych i przypowierzchniowych wodach Atlantyku Północnego. Te zmiany zasobów ciepła $\mathrm{w}$ wodach przejawiają się między innymi w postaci wielkoskalowych zmian temperatury powierzchni oceanu (dalej SST - Sea Surface Temperature) na tej części Atlantyku (Schlesinger i Ramankutty, 1994, Latif i inni, 2004).

Tę długookresową zmienność stanu termicznego Atlantyku Północnego określa się mianem Multidekadowej Oscylacji Atlantyku (skrót AMO - Atlantic Multidecadal Oscillation; Kerr, 2000, Enfield i inni, 2001). Przebieg AMO jest dwufazowy - stan w czasie występowania dodatnich anomalii SST na Atlantyku Północnym nazywany jest dodatnią fazą AMO, spadek anomalii SST poniżej średniej jest określany mianem ujemnej fazy AMO. Kolejne fazy AMO cechuje okresowość 60-80-letnia (Schlesinger i Ramankutty, 1994; Andronova i Schlesinger, 2000; Delworth i Mann, 2000).

Podobnymi pod pewnymi względami do AMO są procesy noszące inne nazwy. Opisują one, za pomocą odmiennych miar (wskaźników) intensywność transportu wód, ciepła i soli z południa na północ Atlantyku Północnego. Takim zjawiskiem jest AMOC (Atlantic Meridional Overturning Circulation; Pohlmann i inni, 2006; Carton, 2011; Carton i inni, 2014), co można tłumaczyć na język polski jako atlantycka południkowa cyrkulacja termohalinowa. Bardzo podobny proces, choć odmiennie zdefiniowany i mierzony, nosi nazwę Atlantyckiego Trybu Południkowego (AMM - Atlantic Meridional Mode; Carton i inni, 1996; Vimont i Kosin, 2007; Grossmann i Klotzbach, 2009).

I. Grossmann i P.J. Klotzbach (2009) oraz L. Zhang i C. Wang (2013) wykazali, że opisywane do niedawna jako osobne zjawiska AMO, AMOC i AMM stanowią różne aspekty tego samego procesu, jakim jest NA THC. Zmienność natężenia NA THC, a więc również AMO, jak wykazują dotychczasowe wyniki badań, stanowi przejaw naturalnej wewnętrznej zmienności systemu klimatycznego (np. Delworth i Knudson, 2000; Andronova i Schlesinger, 2000).

Zmiany zasobów ciepła w wodach Atlantyku Północnego wpływają na rozmiary strumieni ciepła z oceanu do atmosfery, które wymuszają odpowiednie zmiany wielkoskalowej cyrkulacji atmosferycznej. To z kolei stanowi przyczynę długookresowej zmienności warunków klimatycznych nad szeroko rozumianym 
otoczeniem Atlantyku Północnego (np. Delworth i Greatbatch, 2000; Gray i inni, 2004, Sutton i Hodson, 2005, Knight i inni, 2005; Folland i inni, 2009; Kushnir i inni, 2010; Sutton i Dong, 2012). Według licznych badaczy (np. Schlesinger i Ramankutty, 1994; Delworth i Mann, 2000; Knight i inni, 2006; Zhang i inni, 2007; Ting i inni, 2011; Marsz, 2011) wpływ ten jest przestrzennie większy i obejmuje całą półkulę północną, a może zaznacza się nawet w skali globalnej (Chylek i inni, 2014).

D.B. Enfield i inni (2001) wykazali, że nad obszarem Ameryki Północnej zmiany faz AMO pociągają za sobą zmiany rocznego odpływu rzek. W dodatniej fazie AMO sumy opadów nad większą częścią Stanów Zjednoczonych maleją, roczny odpływ Mississippi zmniejsza się o około 10\% w stosunku do średnich przepływów rocznych w ujemnej fazie AMO. Znacznie większe zróżnicowanie przepływów między dodatnią a ujemną fazą AMO Enfield i inni (2001) stwierdzili w strefie tropikalnej - przepływy rzek zasilających jezioro Okeechobee (Floryda) zmieniają się o około 40\%. R.J. Oglesby i inni (2011) wykazali związek między występowaniem w USA w średniowieczu długotrwałych susz z przeważającą dodatnią fazą AMO w tym okresie. Podobnie długotrwałe susze w latach 1930. w środkowych stanach USA wiąże się z ówczesną kulminacją dodatniej fazy AMO (Nigam i inni, 2011).

R.T. Sutton i D. Hodson (2005) stwierdzili, że zmiany SST tropikalnego Atlantyku Północnego wywierają wpływ na klimat Ameryki Północnej, natomiast zmiany SST na obszarze ekstratropikalnym oceanu wywierają silniejszy wpływ na zmienność klimatu Europy. Badacze ci z ujemną fazą AMO wiążą rozpoczynające się w latach 1960. ochłodzenie w Europie, a z następującą po niej dodatnią fazą AMO - wzrost temperatury, występowanie „fal upałów” i przypuszczalny wzrost opadów w Europie. Sutton i Dong (2012) wykazali odmienną reakcję klimatu, a zwłaszcza sezonowych sum opadów na zmiany AMO na obszarach Europy Północnej i Europy Południowej. Podobne zróżnicowanie występowania opadów ekstremalnych między centralną i zachodnią Europą a Europą Południową (Uclee - Kijów, Marsylia) o oscylacyjnym charakterze, odpowiadającym w przybliżeniu ciepłym i chłodnym fazom AMO, przedstawia praca P. Willems (2013). Opracowań poświęconych tym zagadnieniom jest wiele, dotyczą one również związków AMO z opadami i temperaturą powietrza w Azji.

Istnienie opisanych w literaturze długookresowych związków między AMO a opadami, temperaturą powietrza i odpływem rzecznym skłoniło autorów do sprawdzenia, czy między zmiennością wskaźnika AMO a rocznymi przepływami głównych rzek Polski zachodzą podobne związki. Przeprowadzone analizy dały wyniki negatywne. Występujące związki były statystycznie nieistotne. Analiza relacji między wskaźnikiem charakteryzującym intensywność północnoatlantyckiej THC a przepływami głównych rzek Polski wykazała natomiast, że związki między tymi wielkościami istnieją - i choć relatywnie słabe - są wysoce istotne statystycznie. 


\section{Materiały źródłowe, metody opracowania}

Ze względu na długookresowy charakter badanych związków wykorzystano te ciągi rocznych przepływów głównych rzek Polski, które mają najdłuższe okresy obserwacyjne. Jednocześnie postanowiono ograniczyć analizę do czterech profili hydrologicznych kontrolujących dwie największe zlewnie Polski.

Analizie poddano dane o średnich przepływach rocznych (w roku hydrologicznym; $\mathrm{m}^{3} \cdot \mathrm{s}^{-1}$ ) z posterunków wodowskazowych na Wiśle (w Tczewie) i jej prawobrzeżnym dopływie Bugu (w Wyszkowie) oraz na Odrze (w Gozdowicach) i jej największym dopływie - Warcie (w Poznaniu). Wykorzystane profile pomiarowe zlokalizowane są w dolnych biegach wymienionych rzek, zatem dają one pośrednio informacje o kształtowaniu się w danym roku bilansu wodnego w zlewniach Odry i Wisły, czyli na zdecydowanej większości obszaru Polski. Dane o przepływach tych rzek obejmowały następujące okresy:

- Wisły w profilu Tczew - 1901-2015; 1901-1986 według RivDis (Vorosmarty i inni, 1998), uzupełnione danymi IMGW do roku 2015,

- Bugu w profilu Wyszków - 1921-1986 według RivDis, uzupełnione do roku 2015 danymi IMGW,

- Odry w Gozdowicach - 1901-1986 według RivDis, uzupełnione danymi IMGW do roku 2015,

- Warty w Poznaniu - 1822-1988 według K. Olejnika (1991), do roku 2000 uzupełnione przez A. Styszyńską i J. Tamulewicza (2005), a następnie danymi IMGW (2001-2015).

Dodatkowo wykorzystano dane z długiego ciągu pomiarowego Wisły na profilu w Toruniu (1820-2000; bez danych z roku 1945; Makowski i Tomczak, 2002; brakującą wartość z roku 1945 obliczono metodą regresji z przepływów w Tczewie).

Wspólny okres obserwacji wszystkich wymienionych przepływów - to 19212015, czyli 95 lat i ten traktowany jest w przedstawionej analizie jako podstawowy. Jako okres dodatkowy wykorzystano 1822-2000 (dane dotyczące Wisły w Toruniu i Warty w Poznaniu), ze względu na to, że dane o przepływach rocznych Wisły w Toruniu w pracy J. Makowskiego i A. Tomczak (2002) kończą się na roku 2000.

Zmienność przepływów rocznych w najdłuższych szeregach (Wisła w Toruniu, Warta w Poznaniu) rejestruje nie tylko zmiany pod wpływem czynników naturalnych. W wieku XIX i na przełomie XIX i XX, w kilku fazach, prowadzono w zlewniach obu rzek szeroko zakrojone prace melioracyjne i regulacyjne. Następowały też poważne zmiany użytkowania terenu, co mogło wywierać wpływ na wartości przepływów. Postanowiono jednak wykorzystać te dane do analizy, gdyż są to jedyne dostępne dane obserwacyjne, sięgające tak daleko w przeszłość. 
Syntetycznym wskaźnikiem zmienności cyrkulacji termohalinowej (THC)

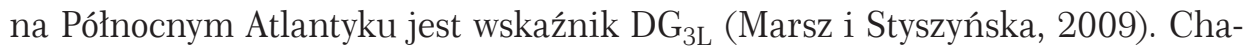
rakteryzuje on ilość ciepła transportowanego wraz z wodami tropikalnymi z delty Golfstromu na północ - do Prądu Północnoatlantyckiego, a następnie, z kolejnymi prądami - do Arktyki. Wzrost wartości wskaźnika $D_{3 L}$ powyżej zera wskazuje na odpowiednio zwiększony względem średniej transport ciepła wraz z wodami tropikalnymi na północ, spadek poniżej zera - na proporcjonalne do wartości wskaźnika zmniejszenie intensywności takiego transportu. Zmiany intensywności transportu wód tropikalnych z delty Golfstromu na północ skutkują zmianami stanu termicznego północnego Atlantyku. Efektem spadku wartości $\mathrm{DG}_{3 \mathrm{~L}}$ jest obniżanie się SST na rozległych powierzchniach akwenów środkowych, wschodnich i północno-wschodnich części Atlantyku Północnego, wzrostu - odwrotnie - wzrost SST na tych samych akwenach. Zmienność wskaźnika $\mathrm{DG}_{3 \mathrm{~L}}$ niesie informację o dwóch procesach jednocześnie - o natężeniu powierzchniowej składowej NA THC, która odzwierciedla natężenie transportu ciepła i soli wraz z wodami oceanicznymi na północ i o AMO, która charakteryzuje znak i wartość anomalii SST na północnym Atlantyku.

Podstawą obliczania wskaźnika $\mathrm{DG}_{3 \mathrm{~L}}$ jest średnia arytmetyczna z miesięcznej temperatury powierzchni oceanu (SST) lutego, sierpnia i września danego roku $(k)$ z powierzchni $2 \times 2^{\circ}$ o współrzędnych centrum $38^{\circ} \mathrm{N}, 056^{\circ} \mathrm{W}$. Wartość tę oznacza się tu jako $\mathrm{G}(k)$. Z wartości $\mathrm{G}$ z kolejnych trzech lat (2 lata wcześniej; $\mathrm{G}(k-2)$, rok wcześniej $(\mathrm{G}(k-1)$ i roku bieżącego $(\mathrm{G}(k)$; gdzie $k$ - numer kolejny roku według kalendarza gregoriańskiego) oblicza się wskaźnik DG datowany na rok bieżący $(k)$ według formuły:

$$
\mathrm{DG}(k)=0,43 \cdot \mathrm{G}(k)+0,32 \cdot \mathrm{G}(k-1)+0,25 \cdot \mathrm{G}(k-2)
$$

Uzyskane w ten sposób wartości DG są następnie standaryzowane względem średniej z lat 1901-2000:

$$
\mathrm{DG}_{3 \mathrm{~L}}(k)=(\mathrm{DG}(k)-23,25) / 0,28
$$

(gdzie stałe 23,25 i 0,28 to odpowiednio średnia stuletnia wartość DG i jej odchylenie standardowe), dając w efekcie wartość bezwymiarową. Uzasadnienie takiej konstrukcji wskaźnika i jego podstaw fizycznych objaśniono w pracy A. Marsza i A. Styszyńskiej (2009) oraz A. Marsza (2015b - zał. 1). W tej ostatniej oraz innej Marsza (2015a) opublikowany jest również szereg czasowy wartości wskaźnika $\mathrm{DG}_{3 \mathrm{~L}}$ obejmujący lata 1880-2015.

Miesięczne wartości SST niezbędne do obliczenia wartości DG pochodzą ze zbioru ERSST v.3b (Smith i inni, 2008). Wartości SST w zbiorze ERSST v.3b obejmują okres od roku 1854 do chwili obecnej, jednak dane zawarte w tym zbiorze poprzedzające rok 1880 obarczone są zbyt dużymi błędami (Smith i inni, 2008), aby można traktować je jak w pełni wiarygodne. Wykorzystuje się zatem w tym miejscu do analizy szereg czasowy wartości $D_{3 \mathrm{~L}}$ od roku 1880, co ogranicza możliwość analizy związków między rocznymi przepływami wybranych 
rzek Polski a $\mathrm{DG}_{3 \mathrm{~L}}$ do 135-letniego okresu, mimo że szeregi obserwacyjne przepływów na Wiśle w Toruniu i Warcie w Poznaniu sięgają jeszcze 60 lat wstecz.

Wskaźnik $\mathrm{DG}_{3 \mathrm{~L}}$ oblicza się na podstawie innych danych wyjściowych oraz w odmienny sposób niż wskaźnik AMO. Z wartości SST potrzebnych do obliczania wskaźnika $\mathrm{DG}_{3 \mathrm{~L}}$ nie są, w odróżnieniu od procedury obliczania $\mathrm{AMO}$, usuwane trendy, nie stosuje się również silnej filtracji dolnoprzepustowej. Niemniej wskaźnik $\mathrm{DG}_{3 \mathrm{~L}}$ jest silnie skorelowany ze wskaźnikami AMO. Z pozbawionym trendu „niewygładzonym” (unsmoothed) wskaźnikiem AMO korelacja jest nieco słabsza $(r=+0,55, p<<0,001 ; 1880-2000)$, bardzo silna $\mathrm{z}$ „wygładzonym” (smoothed) wskaźnikiem AMO $(r=+0,73, p<<0,001)$. Dowodzi to, że w przebiegu wskaźnika $\mathrm{DG}_{3 \mathrm{~L}}$ zawarty jest również silny sygnał $\mathrm{AMO}$.

Przebieg wskaźnika $D_{3 L}$ nie jest powiązany z główną modą cyrkulacji atmosferycznej nad Atlantykiem Północnym, czyli z NAO. Szereg czasowy $\mathrm{DG}_{3 \mathrm{~L}}$ nie jest skorelowany z zimowym wskaźnikiem NAO J.W. Hurrella (1995) ani ze wskaźnikiem rocznym NAO CRU (Jones i inni, 1997). Wspó1czynniki korelacji między $\mathrm{DG}_{3 \mathrm{~L}}$ a tymi wskaźnikami wynoszą odpowiednio $+0,07$ (1880-2000) i-0,01 (1880-2000).

$\mathrm{W}$ pracy zastosowano powszechnie znane metody analizy statystycznej korelację liniową, analizę regresji i analizę wariancji oraz analizę składowych głównych.

\section{Wyniki}

W przepływach rzek Polski, mimo dużej zmienności międzyrocznej, zaznacza się wspólny rytm zmienności, zarówno krótko-, jak i długookresowej. Analiza korelacji we wspólnym okresie obserwacji przepływów wykazuje, że między przepływami rocznymi rozpatrywanych tu rzek występują silne i wysoce istotne związki (tab. 1).

Tabela 1. Wartości współczynników korelacji liniowej $(r)$ między przepływami rocznymi głównych rzek Polski i ich istotność statystyczna $(p)$. Analizowany okres 1921-2015

Linear correlation coefficients $(r)$ between mean annual discharges of the main rivers in Poland and its statistical significance $(p)$. Analysed years 1921-2015

\begin{tabular}{|c|c|c|c|c|}
\hline \multicolumn{2}{|c|}{} & $\begin{array}{c}\text { Bug; } \\
\text { Wyszków }\end{array}$ & $\begin{array}{c}\text { Warta; } \\
\text { Poznań }\end{array}$ & $\begin{array}{c}\text { Odra; } \\
\text { Gozdowice }\end{array}$ \\
\hline Wisła; & $r$ & 0,88 & 0,81 & 0,75 \\
Tczew & $p$ & $<0,001$ & $<0,001$ & $<0,001$ \\
Bug; & $r$ & $\mathrm{X}$ & 0,66 & 0,60 \\
Wyszków & $p$ & & $<0,001$ & $<0,001$ \\
Warta; & $r$ & & $\mathrm{X}$ & 0,93 \\
Poznań & $p$ & & $<0,001$ \\
\hline
\end{tabular}

Opracowanie własne, podobnie jak pozostałe tabele i ryciny. / Author’s own elaboration, as well as other tables and figures. 
Podobnie silne są związki między przepływami w najdłuższych szeregach obserwacyjnych. Między szeregiem rocznych przepływów Wisły w profilu Toruń a przepływami rocznymi Warty w profilu Poznań (178 lat; 1822-2000) występuje również silny związek - współczynnik korelacji jest równy $+0,66$, czyli niewiele słabszy niż w krótszym - 80-letnim okresie 1921-2000 (+0,71).

Szeregi przepływów rocznych na czterech profilach z okresu 1921-2015 poddano analizie składowych głównych (PCA). Analiza ujawniła istnienie tylko jednej składowej głównej o wartości własnej większej od 1,0, która objaśnia 82,87\% wariancji zmiennych. W sensie fizycznym wartości czynnikowe pierwszej składowej głównej stanowią średnią ze standaryzowanych przepływów rocznych. W całym 95-letnim szeregu czasowym wartości czynnikowych (1 wektor własny) brak statystycznie istotnego trendu. Przebieg tego szeregu wyrównany wielomianem piątego stopnia wykazuje natomiast, że na tle dużej zmienności międzyrocznej zaznaczają się subtrendy o rosnących i malejących przepływach (ryc. 1). Odtwarzają one przebieg wielodekadowych zmian natężenia przepływów. Takie kształtowanie się współczynników korelacji i duża wartość zmienności wspólnej (kowariancji) pozwala twierdzić, że wspólny rytm krótko- i długookresowych zmian przepływów rocznych jest charakterystyczny dla rzek Polski w XIX i XX w.

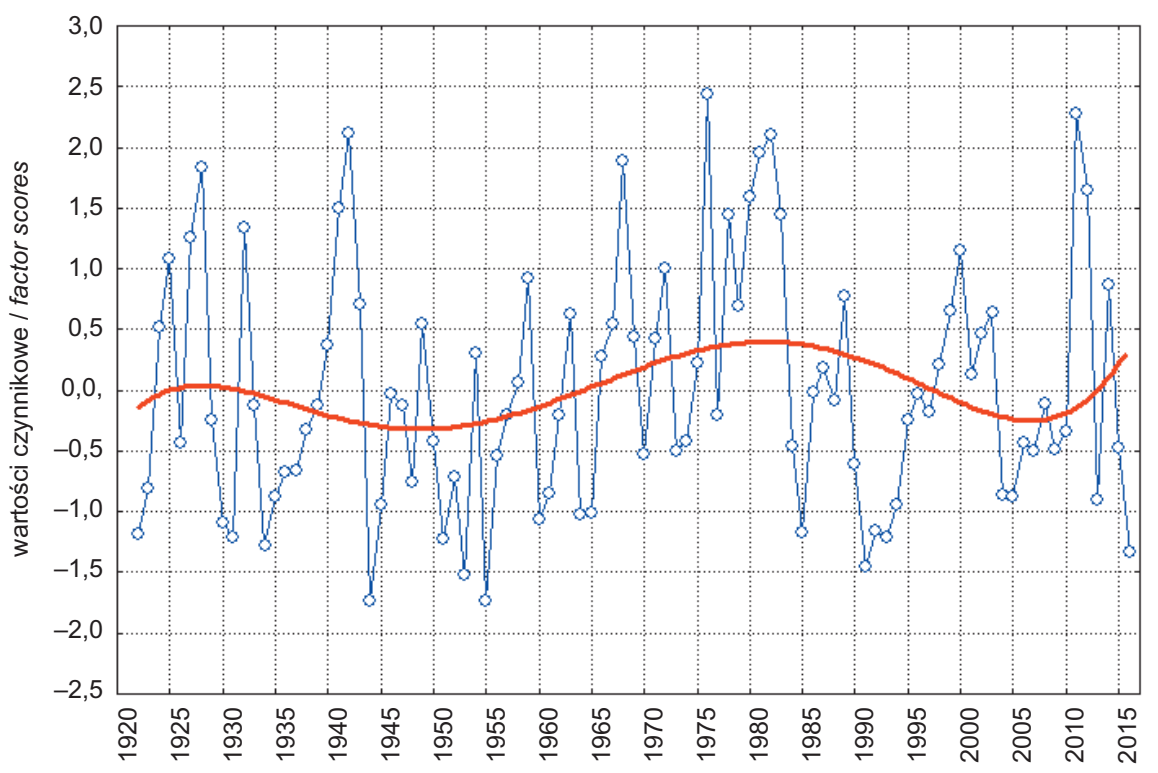

Ryc. 1. Seria czasowa wartości czynnikowych (1 wektora własnego) przepływów rocznych rzek uwzględnianych w analizie. Czerwona linia ciągła - przebieg wyrównany wielomianem piątego stopnia

Time series for principal (first eigenvector) values for annual discharges of the rivers analysed.

The red continuous line is the course smoothed with a fifth-order polynomial 
Związki między przepływami rocznymi rzek Polski a wskaźnikiem $D_{3 \mathrm{~L}}$ w 95-leciu 1921-2015 są słabe, ale bez wyjątku istotne statystycznie (tab. 2). Wartości współczynników korelacji cechuje małe zróżnicowanie, wszystkie mają taki sam ujemny znak. Współczynnik korelacji między wskaźnikiem $D_{3 \mathrm{~L}}$ a szeregiem wartości czynnikowych (1 wektor własny) przepływów rzek uwzględnianych w tej analizie jest równy $-0,345(p<<0,001)$. Oznacza to, że wraz ze wzrostem wartości wskaźnika $D_{3 \mathrm{~L}}$ przepływy roczne rzek Polski zmniejszają się. Analiza regresji wykazuje, że w latach 1921-2015 zmiana wartości wskaźnika $\mathrm{DG}_{3 \mathrm{~L}}$ o jedną jednostkę pociąga za sobą zmianę z przeciwnym znakiem średniego rocznego przepływu czterech największych rzek Polski o 32,1( $\pm 9,7)$ $\mathrm{m}^{3} \cdot \mathrm{s}^{-1}$ (przy średnim rocznym przepływie wymienionych czterech rzek równym $454,2( \pm 11,0) \mathrm{m}^{3} \cdot \mathrm{s}^{-1}$.

Tabela 2. Współczynniki korelacji $(r)$ między rocznymi przepływami wybranych rzek w Polsce a wskaźnikiem $D_{3 \mathrm{~L}}$ i ich istotność statystyczna $(p)$. Analizowany okres 1921-2015

Corellation coefficients $(r)$ between mean annual discharges of analysed rivers and the $\mathrm{DG}_{3 \mathrm{~L}}$ index and its statistical significance $(p)$. Analysed years 1921-2015

\begin{tabular}{|c|c|c|c|c|c|}
\hline \multicolumn{2}{|c|}{} & $\begin{array}{c}\text { Wisła; } \\
\text { Tczew }\end{array}$ & $\begin{array}{c}\text { Bug; } \\
\text { Wyszków }\end{array}$ & $\begin{array}{c}\text { Warta; } \\
\text { Poznań }\end{array}$ & $\begin{array}{c}\text { Odra; } \\
\text { Gozdowice }\end{array}$ \\
\hline DG $_{3 \mathrm{~L}}$ & $r$ & $-0,29$ & $-0,29$ & $-0,32$ & $-0,32$ \\
& $p$ & 0,005 & 0,005 & 0,002 & 0,001 \\
\hline
\end{tabular}

Związki te charakteryzuje dość wyraźna liniowość, a ich cechą szczególną jest większe skupienie wokół linii regresji wartości przepływów przy dodatnich wartościach wskaźnika $\mathrm{DG}_{3 \mathrm{~L}}$ niż w latach występowania ujemnych wartości tego wskaźnika, co przykładowo przedstawia rycina 2. Na wszystkich analizowanych tu rzekach zaznacza się tendencja do wystąpienia najwyższych wartości przepływów rocznych przy ujemnych wartościach $\mathrm{DG}_{3 \mathrm{~L}}$, czyli w okresie osłabienia natężenia NA THC.

W dłuższym okresie 1880-2000 (121 lat) współczynniki korelacji między przepływami Wisły w profilu Toruń i Warty w profilu Poznań a wskaźnikiem $\mathrm{DG}_{3 \mathrm{~L}}$ wynoszą odpowiednio -0,2881 $(p<0,001)$ i $-0,2735(p<0,003)$. Jeśli uwzględnić wartość błędu standardowego współczynników korelacji $( \pm 0,012)$, można stwierdzić, że w długim okresie siła związku między przepływem rocznym w obu rzekach a $D_{3 L}$ jest taka sama. Takie kształtowanie się wartości współczynników korelacji w okresach o różnej długości pozwala wnioskować, że ogólny charakter związku między przepływami rocznymi rzek w Polsce a $\mathrm{DG}_{3 \mathrm{~L}}$ jest stabilny w czasie.

Analiza wykresów rozrzutu punktów w przestrzeni wspólnej $\mathrm{DG}_{3 \mathrm{~L}}$ i przepływów rocznych w najdłuższych zbiorach (ryc. 3) pozwala dostrzec kilka cech charakterystycznych. Zwraca uwagę duży rozrzut punktów wokół prostej regresji, 


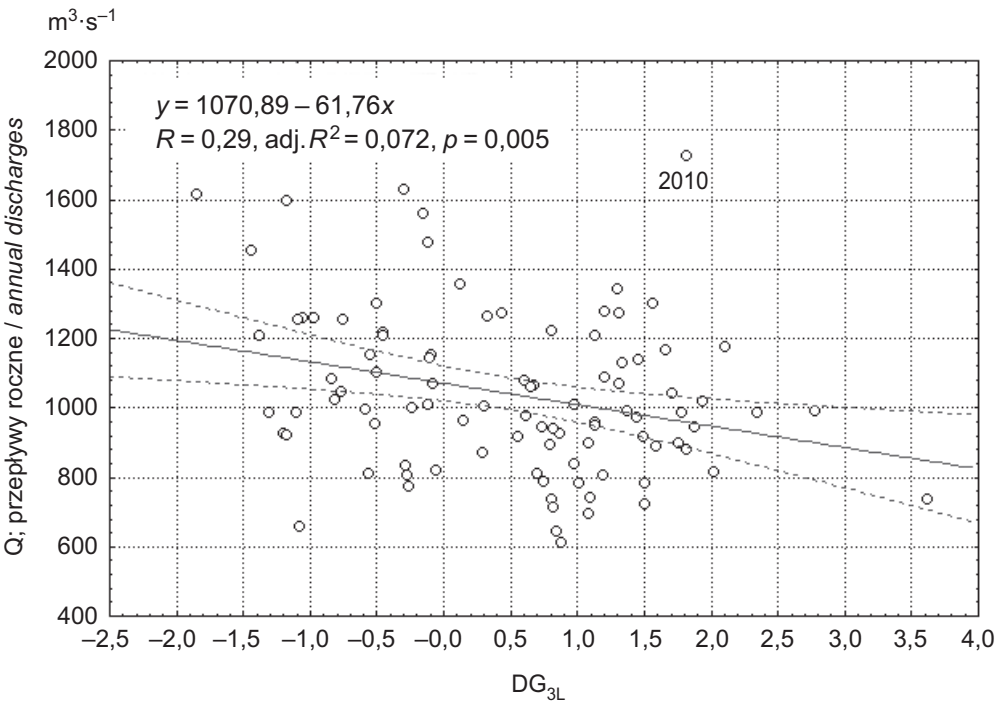

Ryc. 2. Przepływy roczne Wisły (profil Tczew) w funkcji wskaźnika $D_{3 L}$, charakteryzującego zmiany natężenia THC na Atlantyku Północnym (1921-2015). Oznaczono wartość odstającą (rok 2010)

Annual discharges of the Vistula at the Tczew profile, as a function of the $\mathrm{DG}_{3 \mathrm{~L}}$ index characterising changes in the intensity of the NA THC (1921-2015). An outlier year (2010) is marked

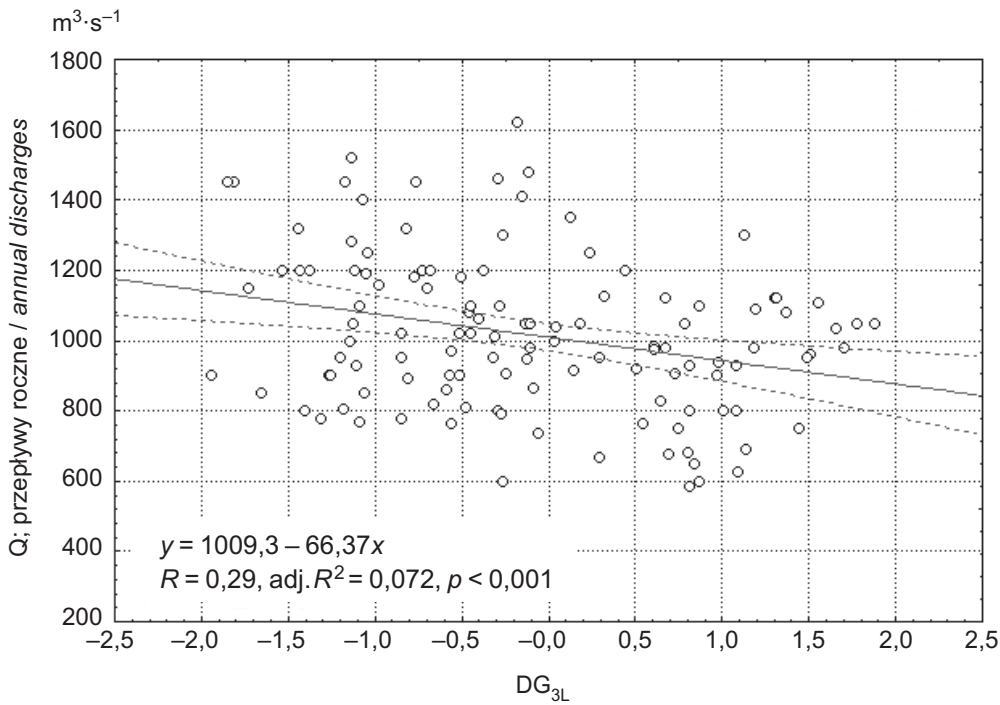

Ryc. 3. Przepływy roczne Wisły w Toruniu w funkcji wskaźnika $D_{3 L}$ (1880-2000) Correlation between mean annual discharges of the Vistula at Torun and the $\mathrm{DG}_{3 \mathrm{~L}}$ index (1880-2000) 

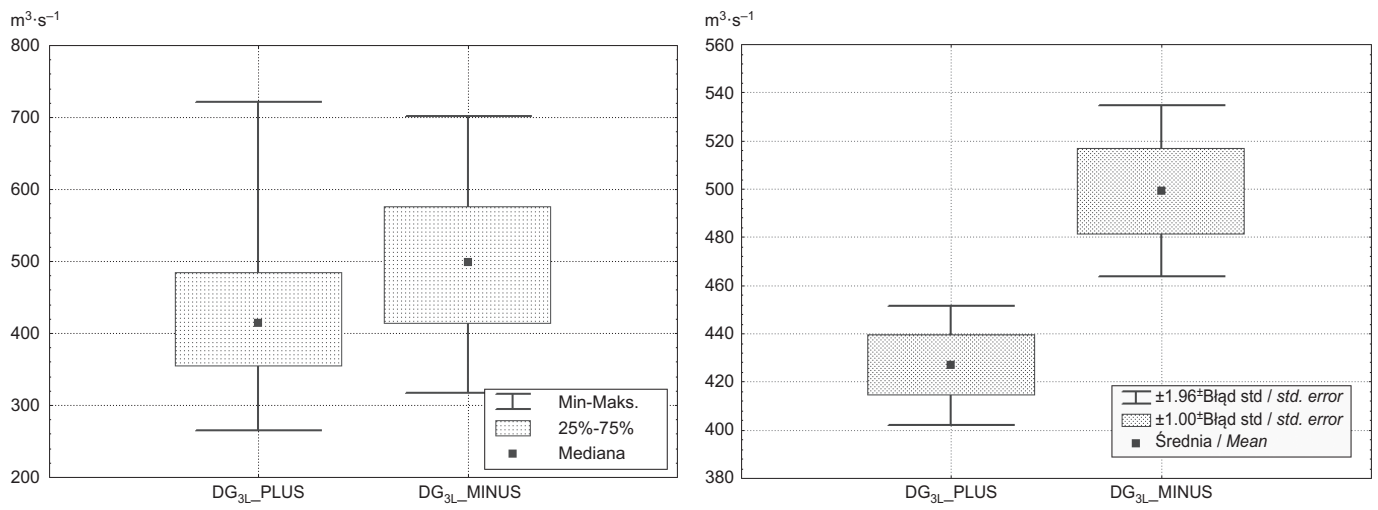

Ryc. 4. Lewy panel: Zakres zmienności średnich (z 4 profilów) przepływów rocznych głównych rzek Polski w latach z dodatnimi wartościami wskaźnika DG $_{3 \mathrm{~L}}$ (59 przypadków) i w latach z ujemnymi wartościami tego wskaźnika (36 przypadków)

Prawy panel: Różnice między średnimi rocznymi przepływami w latach z dodatnimi wartościami wskaźnika $\mathrm{DG}_{3 \mathrm{~L}}$, a średnimi rocznymi przepływami w latach z ujemnymi wartościami wskaźnika DG $_{3 \mathrm{~L}}$ i ocena ich błędów standardowych Przepływy z okresu 1921-2015.

Różnica między średnimi jest wysoce istotna statystycznie (test dwustronny: $p=0,001$ )

Left: Range of variability to mean annual discharges from the main rivers in Poland (4 profiles) during years with positive $\mathrm{DG}_{3 \mathrm{~L}}$ index values (59 cases), as opposed to those with negative $\mathrm{DG}_{3 \mathrm{~L}}$ values (36 cases)

Right: Differences between mean annual discharges during years with positive $\mathrm{DG}_{3 \mathrm{~L}}$ index values and those with a negative $\mathrm{DG}_{3 \mathrm{~L}}$ index, together with standard errors. Discharges in the years 1921-2015 inclusive. The difference between these means does achieve statistical significance (bilateral test, $p=0.001$ )

wskazujący na dużą zmienność międzyroczną przepływów i ich stosunkowo słabe powiązanie z $\mathrm{DG}_{3 \mathrm{~L}}$. O słabym skorelowaniu przepływów rocznych w obu rzekach z $\mathrm{DG}_{3 \mathrm{~L}}$ decyduje duży rozrzut najwyższych przepływów, przepływy niskie i średnie wykazują zaś znacznie większe skupienie. Nachylenia prostych regresji są niewielkie, wskazujące na relatywnie niewielki wpływ zmian wartości wskaźnika $\mathrm{DG}_{3 \mathrm{~L}}$ na przepływy roczne. Zmienność wskaźnika $\mathrm{DG}_{3 \mathrm{~L}}$ objaśnia w 121-leciu zaledwie 8,3\% wariancji rocznych przepływów Wisły w Toruniu i 7,5\% wariancji rocznych przepływów Warty w Poznaniu. W krótszym, 95-letnim okresie 1921-2015, zmienność DG $_{3 \mathrm{~L}}$ objaśnia nieco więcej, bo 10,3\% wariancji pierwszego wektora własnego rocznych przepływów rzek uwzględnianych w analizie. Taki obraz pozwala postawić tezę, że korelacje między przepływami rocznymi a wskaźnikiem $D_{3 \mathrm{~L}}$ są wynikiem wspólnych, niezbyt silnych, długookresowych subtrendów w tych szeregach.

Dla okresu 1921-2015 obliczono z przepływów rocznych na czterech profilach „średni” roczny przepływ (nienormalizowany, $\mathrm{m}^{3} \cdot \mathrm{s}^{-1}$ ), a następnie pogrupowano wartości przepływów w latach o dodatnich wartości wskaźnika $\mathrm{DG}_{3 \mathrm{~L}}(59$ przy- 
padków) i przepływy w latach z ujemnymi wartościami tego wskaźnika (36 przypadków). Oszacowana średnia arytmetyczna dla przypadków przepływów „średnich" w latach z dodatnim wskaźnikiem intensywności NA THC $\left(426,81 \mathrm{~m}^{3} \cdot \mathrm{s}^{-1}\right.$; $\sigma=96,97)$ jest wyraźnie mniejsza od średniej $\left(499,01 \mathrm{~m}^{3} \cdot \mathrm{s}^{-1} ; \sigma=108,5\right)$ oszacowanej dla lat z ujemnymi wartościami wskaźnika $\mathrm{DG}_{3 \mathrm{~L}}$. Testowanie wykazało, że istotność różnicy między średnimi jest wysoka (test dwustronny: $p=0,0011$ ).

Opisana procedura potwierdza, że między przeciętnymi przepływami rocznymi rozpatrywanych rzek Polski w latach z odmiennymi znakami wskaźnika $\mathrm{DG}_{3 \mathrm{~L}}$ są różnice o wysokiej istotności statystycznej, a dodatkowo - co stwierdzono już wcześniej - rzeczywiście zmienia się zakres zmienności (patrz wartości $\sigma$ ). Zmienia się również charakter rozkładu przepływów rocznych (ryc. 5) w zależności od znaku fazy NA THC (wskaźnika $D_{3 \mathrm{~L}}$ ). W latach z dodatnimi wartościami wskaźnika $\mathrm{DG}_{3 \mathrm{~L}}$ przepływy nie tylko są mniejsze, ale również mają zmniejszony zakres zmienności. Jest to doskonale widoczne, mimo że w podzbiorze wartości przepływów rocznych w okresie o dodatnim wskaźniku $\mathrm{DG}_{3 \mathrm{~L}}$ znajduje się wartość silnie odstająca - największy przepływ Wisły w całym analizowanym okresie, jaki odnotowano w roku 2010. Przypadek ten związany jest

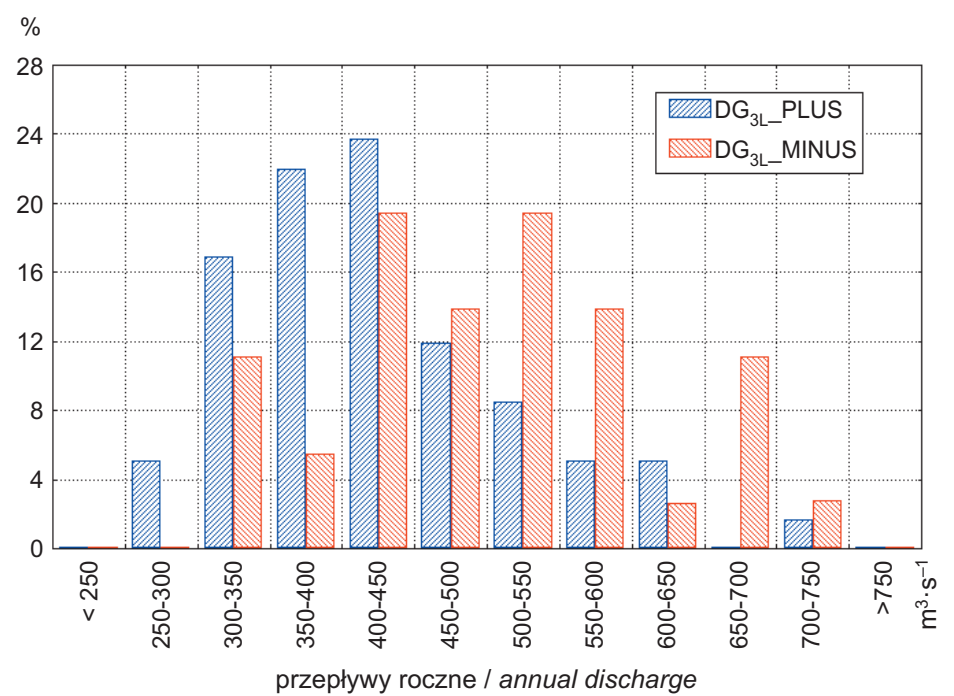

Ryc. 5. Histogram rozkładu wartości przepływów rocznych (Q; średnie z 4 profili; $\mathrm{m}^{3} \cdot \mathrm{s}^{-1}$ ) przy dodatnich ( $\mathrm{DG}_{3 \mathrm{~L} \_}$PLUS) i ujemnych ( $\mathrm{DG}_{3 \mathrm{~L} \_}$MINUS) wartościach wskaźnika DG $_{3 \mathrm{~L}}$. Wobec nierównej liczności przypadków (patrz podpis pod ryc. 4) histogram przedstawia rozkład \% przypadków w dodatniej (suma 100\%) i ujemnej (suma 100\%) fazie wskaźnika

Histogram for the distribution of annual discharge values (Q; averages from 4 profiles; $\mathrm{m}^{3} \cdot \mathrm{s}^{-1}$ ) in the circumstances of positive or negative $\mathrm{DG}_{3 \mathrm{~L}}$ indices, i.e. $\mathrm{DG}_{3 \mathrm{~L}-}$ PLUS and $\mathrm{DG}_{3 \mathrm{~L}-}$ MINUS. Because of the uneven number of cases (59 and 36) this histogram presents a percentage distribution of cases coinciding with positive and negative phases characterising the $\mathrm{DG}_{3 \mathrm{~L}}$ indicates (total equals $100 \%$ in each case). 
z występującą w tym roku długotrwałą letnią powodzią w dorzeczu Wisły; wielkie przepływy w czasie tej powodzi wywarły istotny wpływ na wartość przepływu rocznego (patrz ryc. 2).

Przebieg natężenia THC cechuje się długookresową zmiennością, w przebiegu wskaźnika $\mathrm{DG}_{3 \mathrm{~L}}$ zaznacza się około 70-letnia okresowość (ryc. 6). Wyraźnie zaznaczają się okresy, w których średnia jego wartość jest mniejsza od zera (ujemna faza $\mathrm{DG}_{3 \mathrm{~L}}$ ) i większa od zera (faza dodatnia), przy czym przejścia między fazami są gwałtowne, natomiast trudno jednoznacznie określić momenty wystąpienia minimów i maksimów poszczególnych faz (ryc. 6). Jeśli granice między fazami przyjąć jako przejście wartości wskaźnika przez zero, można wyróżnić (patrz ryc. 6) następujące kolejno po sobie fazy zmienności wskaźnika $\mathrm{DG}_{3 \mathrm{~L}}$ :

- 1880-1927 - faza ujemna,

- 1928-1963 - faza dodatnia,

- 1964-1988 - faza ujemna,

- 1989-2015 - faza dodatnia.

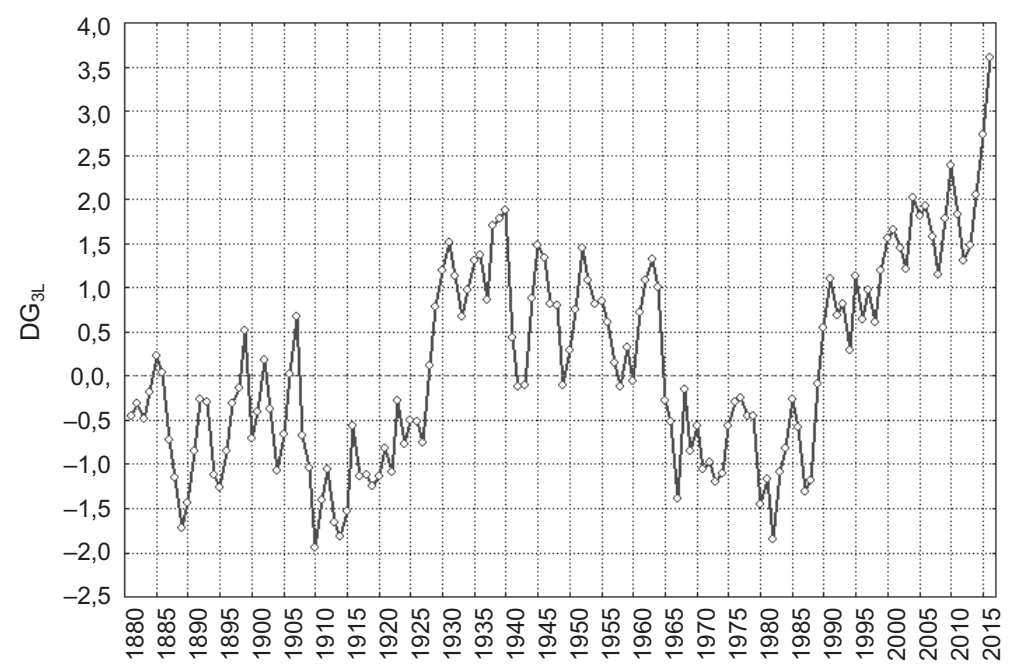

Ryc. 6. Przebieg wartości wskaźnika $D_{3 \mathrm{~L}}$ w latach 1880-2015

Time series for the $\mathrm{DG}_{3 \mathrm{~L}}$ index in the years 1880-2015

Wobec stwierdzenia związków statystycznych między wartością przepływu rocznego rzek Polski a znakiem wartości wskaźnika $D_{3 \mathrm{~L}}$, jest niemal oczywiste, że zmiany faz natężenia THC na północnym Atlantyku powinny pociągać za sobą odpowiednie, długookresowe zmiany przepływów rocznych. Zmiany rozmiarów przepływów w poszczególnych fazach zmian wskaźnika $D_{3 \mathrm{~L}}$ zbadano w najdłuższych ciągach (1880-2000), z tym, że tylko dwa okresy (1928-1963 
i 1964-1988) odpowiadają w tych ciągach pełnym długościom faz. Zestawienie średnich wartości wskaźnika $\mathrm{DG}_{3 \mathrm{~L}}$ w poszczególnych fazach i średnich przepływów Wisły w Toruniu oraz Warty w Poznaniu w tych samych okresach przedstawia tabela 3 .

Tabela 3. Średnie wartości wskaźnika $\mathrm{DG}_{3 \mathrm{~L}}$ i jego zmienność $(\sigma)$ w kolejnych fazach ujemnych i dodatnich przebiegu wskaźnika oraz średnie przepływy roczne Wisły w Toruniu i Warty w Poznaniu $\left(\mathrm{m}^{3} \cdot \mathrm{s}^{-1}\right)$ i ich zmienność ( $\sigma$ - odchylenie standardowe) w tych samych okresach

Mean $\mathrm{DG}_{3 \mathrm{~L}}$ index and its variability $(\sigma)$ in the successive negative and positive phases of its course. Mean annual diacharges of the Vistula river at Torun and the Warta at Poznań $\left(\mathrm{m}^{3} \cdot \mathrm{s}^{-1}\right)$ and its variability $(\sigma-$ standard deviation) during the same time

\begin{tabular}{|l|c|c|c|c|}
\hline \multirow{2}{*}{$\begin{array}{c}\text { Zmienna } \\
\text { Variable }\end{array}$} & \multicolumn{4}{|c|}{ Okres (lat) / Period (years) } \\
\cline { 2 - 5 } & $\begin{array}{c}1880-1927 \\
(48)\end{array}$ & $\begin{array}{c}1928-1963 \\
(35)\end{array}$ & $\begin{array}{c}1964-1988 \\
(25)\end{array}$ & $\begin{array}{c}1989-2000 \\
(12)\end{array}$ \\
\hline DG $_{3 \mathrm{~L}}$ & $-0,71$ & $+0,86$ & $-0,80$ & $+0,93$ \\
& $\sigma=0,61$ & $\sigma=0,56$ & $\sigma=0,47$ & $\sigma=0,41$ \\
Wisła; Toruń & 1090,6 & 959,7 & 1043,0 & 832,3 \\
& $\sigma=210,75$ & $\sigma=181,54$ & $\sigma=240,05$ & $\sigma=189,81$ \\
Warta; Poznań & 100,6 & 92,2 & 116,5 & 85,5 \\
& $\sigma=27,81$ & $\sigma=34,47$ & $\sigma=29,68$ & $\sigma=27,37$ \\
\hline
\end{tabular}

Stwierdzono, że istnieje związek między fazą $\mathrm{DG}_{3 \mathrm{~L}}$ a średnimi wartościami przepływów. W czasie ujemnych faz $\mathrm{DG}_{3 \mathrm{~L}}$ średnie wartości przepływów rocznych Wisły i Warty są wyższe, w trakcie dodatnich faz $\mathrm{DG}_{3 \mathrm{~L}}$ przepływy zmniejszają się (okres 1880-2000). Jeżeli uwzględni się błędy standardowe estymacji średnich, okazuje się, że różnice średnich wartości przepływów między poszczególnymi fazami dodatnimi a ujemnymi $\mathrm{DG}_{3 \mathrm{~L}}$, choć nieduże, są statystycznie istotne. Jeśli uwzględni się tylko dwa okresy, których czas trwania nie budzi wątpliwości (1928-1963 i 1964-1988), różnice między średnimi przepływami w fazie dodatniej a średnimi przepływami rocznymi w fazie ujemnej (wyrażone w \% przepływów fazy ujemnej) sięgają w przypadku Wisły w Toruniu 8\%, a Warty w Poznaniu 20\%. W przypadku średnich rocznych przepływów na rozpatrywanych 4 profilach, w dodatniej fazie NA THC (1928-1963) średni przepływ roczny wynosi 423,9 $\mathrm{m}^{3} \cdot \mathrm{s}^{-1}(\sigma=96,03)$, a w fazie ujemnej (1964-1988) $507,5 \mathrm{~m}^{3} \cdot \mathrm{s}^{-1}(\sigma=107,88)$. Jest to różnica większa, sięgająca $\sim 16 \%$ rozmiaru przepływów w fazie ujemnej. Trudno ocenić, w jakim stopniu uzyskane oceny różnic rozmiarów przepływów, wobec analizy jednostkowego przypadku, można ekstrapolować. Można jednak szacować, że przeciętne roczne przepływy rzek w Polsce w dodatniej fazie NA THC są od kilku do kilkunastu procent mniejsze, w przybliżeniu o około 10\%, od przepływów w ujemnej fazie cyrkulacji termohalinowej Atlantyku Północnego. 


\section{Dyskusja i wnioski}

Liczne prace (np. Jokiel i Kożuchowski, 1989; Gutry-Korycka i Boryczka, 1990; Styszyńska i Tamulewicz, 2005; Piętka, 2009) wykazały istnienie związków odpływu sezonowego i rocznego rzek Polski ze zmiennością elementów klimatycznych - przede wszystkim sum opadów i temperatury powietrza. Badano również związki między zmiennością odpływów sezonowych i rocznych rzek Polski i Europy a zmiennością różnych wzorców (mód) cyrkulacji atmosferycznej - najczęściej NAO (np. Pociask-Karteczka i inni, 2002-2003; Styszyńska i Tamulewicz, 2005; Pociask-Karteczka, 2006; Wrzesiński, 2011; Wrzesiński i Paluszkiewicz, 2011).

Istnienie wieloletnich fluktuacji w szeregach czasowych przepływów sezonowych i rocznych Wisły i Odry z lat 1901-1980 wykazali P. Jokiel i K. Kożuchowski (1989). Badacze ci, prowadząc analizę widmową serii przepływów rocznych tych rzek, zwrócili uwagę na fakt pojawiania się w analizowanych szeregach ,...tendencji do okresowości osiemdziesięcioletniej. Cykl ten, w rzeczywistości prawdopodobnie nieco krótszy, odpowiada wieloletnim „wiekowym” fluktuacjom klimatycznym, przejawiającym się w Polsce charakterystycznymi zmianami stopnia kontynentalizacji klimatu" (jw., s. 75). Również inni badacze zwrócili uwagę na występowanie w przepływach rocznych rzek Polski „długich cykli” (np. Gutry-Korycka i Boryczka, 1990). Formalnym rezultatem występowania tych fluktuacji jest to, że wraz ze zmianą długości szeregu czasowego przepływów rocznych rzek Polski uzyskuje się okresowo zmieniające się znaki współczynników kierunkowych trendów długookresowych (Wrzesiński, 2009).

Prowadzone do tej pory badania nad zmiennością przepływów rocznych rzek Polski nie wyjaśniają, co jest przyczyną tej długookresowej, multidekadowej zmienności. W świetle przedstawionych wyników analiz nad związkami przepływów rocznych rzek Polski z NA THC można z dużym prawdopodobieństwem twierdzić, że odkryte przez Jokiela i Kożuchowskiego (1989) fluktuacje przepływów, odpowiadające „wiekowym” fluktuacjom klimatu, są sterowane przez zmienność NA THC. Wniosek ten uprawdopodobniają wyniki badań D. Wrzesińskiego (2009), który stwierdził zmianę trendu przepływów rzek Polski z rosnących na malejące w latach 1970., czyli w okresie wystąpienia przybliżonego minimum ostatniej ujemnej fazy NA THC.

Jakie zatem są, lub mogą być, mechanizmy związków między intensywnością NA THC a przepływami głównych rzek Polski? Przepływy roczne dają najbardziej ogólną informację o bilansie wodnym w zlewniach, zmienność międzyroczną bilansu reguluje przede wszystkim taka sama zmienność sum opadowych i temperatury powietrza.

Wzrostowi wskaźnika $\mathrm{DG}_{3 \mathrm{~L}}$ odpowiada wzrost SST na zachodniej i środkowej części tropikalnego Atlantyku Północnego oraz na północno-wschodniej części 
Atlantyku Północnego, aż po morza Arktyki Atlantyckiej. Można oczekiwać, że w okresach, w których SST Atlantyku Północnego jest wyższa od przeciętnej, czyli w okresach dodatniej fazy $\mathrm{DG}_{3 \mathrm{~L}}$ (+NA THC), powinien wystąpić wzrost intensywności parowania z powierzchni oceanu, a tym samym intensyfikacja strumieni pary wodnej, niesionej następnie przez cyrkulację atmosferyczną na wschód, nad Europę, w tym i nad Polskę. Mogłoby to spowodować wzrost opadów nad obszarem północnej i środkowej Europy, w tym nad Polską. W takiej sytuacji należałoby się spodziewać występowania dodatnich korelacji między przepływami rzek Polski a wskaźnikiem $\mathrm{DG}_{3 \mathrm{~L}}$. Jak wykazuje przeprowadzona analiza, jest odwrotnie. Stanowi „cieplejszego” północnego Atlantyku odpowiada zmniejszenie przepływów, natomiast „chłodniejszego” oceanu - zwiększenie przepływów wody w rzekach i wzrost ich międzyrocznej zmienności. Oznacza to, że wpływ zmienności $\mathrm{DG}_{3 \mathrm{~L}}$ na kształtowanie zmienności przepływów rzek w Polsce jest pośredni i zmiany stanu termicznego Atlantyku Północnego działają poprzez kształtowanie innych niż parowanie z powierzchni oceanu procesów wymuszających długookresowe zmiany poszczególnych elementów klimatu Polski.

Studia modelowe H. Pohlmanna i innych (2006) wykazały, że zmienność AMOC wpływa na zmienność klimatu Europy. W czasie wzmożonego transportu ciepła na północ (dodatnia faza AMOC) następuje wzrost rocznej temperatury powietrza nad Europą średnio o 0,5 K, przy czym wpływ ten jest najsilniejszy w rejonie Bałtyku, gdzie dochodzi do $1 \mathrm{~K}$. Maleje częstość występowania dni w roku z temperaturą niższą od $0^{\circ} \mathrm{C}$, rośnie częstość dni z dobową temperaturą wyższą od $25^{\circ} \mathrm{C}$, opady nad obszarem Polski nieznacznie się zmniejszają (Pohlmann i inni, 2006 - ryc. 3). W czasie ujemnych faz AMOC zachodzą zmiany odwrotne.

Wzmożenie AMOC, czyli nasilenie NA THC (któremu odpowiada wzrost wskaźnika $\mathrm{DG}_{3 \mathrm{~L}}$ ), z niewielkim przesunięciem czasowym, prowadzi do wystąpienia dodatniej fazy AMO. W dodatniej fazie AMO, jak wynika z badań R.T. Suttona i D. Hodsona $(2005,2007)$ następuje nad Europą wzrost temperatury, szczególnie wyraźny latem i pewne zmniejszenie się letnich sum opadów. Reakcja przepływów rzek Polski na zmiany indeksu AMO jest jednak bardzo słaba.

Przepływy roczne rzek Polski w wieloleciu 1921-2000 nie wykazują powiązania z „wyrównanym” wskaźnikiem AMO, jedynie przepływy na Bugu w Wyszkowie są z nim istotnie skorelowane. Korelacje te są słabe, zdecydowanie słabsze od korelacji ze wskaźnikiem $D_{3 L}$. Co natomiast ważne: niezależnie od tego czy współczynniki korelacji z „wyrównanym” wskaźnikiem AMO są istotne czy nie, wszystkie one mają taki sam - ujemny - znak, podobnie jak współczynniki korelacji ze wskaźnikiem $\mathrm{DG}_{3 \mathrm{~L}}$. „Niewyrównany” wskaźnik AMO nie wykazuje korelacji z przepływami rzek Polski, wartości współczynników korelacji, poza przepływami Bugu, są bliskie zero.

Powiązanie sum opadów i temperatury ze zmianami faz AMO, wskazane w cytowanych wyżej pracach sugeruje, że zmiany SST na Atlantyku Północ- 
nym, poprzez zmianę rozmiarów i lokalizacji strumieni ciepła z powierzchni oceanu do atmosfery zmieniają położenie osi i amplitudę fal długich (fal Rossby'ego) w środkowej troposferze, co następnie przekłada się na zmiany charakteru dolnej cyrkulacji atmosferycznej (Czaja i Frankignoul, 1999; Frankignoul i inni, 2003; Gulev i inni, 2013). Zmiany dolnej cyrkulacji atmosferycznej z kolei stanowią przyczynę zmian temperatury powietrza i sum opadów rocznych oraz ich rozkładu w czasie. Hipotezę o przesuwaniu się osi prądu strumieniowego (jet stream) półkuli północnej z południa na północ w dodatnich fazach AMO, z czym powiązane są zmiany cyklu rocznego opadów i ich sum rocznych, postawili ostatnio I. Zvieryaev (2009) i J.A. Screen (2013). Stwierdzenia te dobrze korespondują z wynikami badań R. Oglesby i innych (2012) o zmianie położenia wyżów subtropikalnych - ich przesuwaniu się na północ i wschód w czasie dodatniej fazy AMO. Położenie „klimatycznych” układów antycyklonalnych jest z kolei ściśle powiązane z przebiegiem górnej planetarnej strefy frontalnej, z ułożeniem której związany jest przebieg prądu strumieniowego. Obraz przyczyn i skutków zmian temperatury i sum opadowych w Europie (Pohlmann i inni, 2006; Sutton i Hodson, 2005, 2007) jest zatem spójny z interpretacją procesów zachodzących w środkowej i dolnej troposferze (Zvieryaev, 2006; Screen, 2013; Oglesby i inni, 2012).

Przy przesunięciu osi prądu strumieniowego na północ w czasie dodatniej fazy NA THC należy się liczyć z odpowiednim przesunięciem wschodniego skraju Wyżu Azorskiego i tym samym, w ciepłej porze roku, znalezienia się obszaru Polski częściej niż przeciętnie w strefie cyrkulacji z napływami powietrza znad południowo-zachodniej i południowej Europy. Powinno to prowadzić do wzrostu temperatury powietrza i zmniejszenia się sum opadów, tak jak wynika to z badań H. Pohlmana i innych (2006).

Jak wspomniano, w przebiegu NA THC (wartości wskaźnika DG $_{3 \mathrm{~L}}$ ) w latach 1880-2010 zaznacza się okresowość 70-letnia. Bardzo podobną (65-70 lat) okresowość wykrywa się w przebiegu AMO (Schlesinger i Ramankutty, 1994). Z. Kaczorowska (1962) analizując serie rocznych sum opadów w Polsce wykazała występowanie w niej okresowości 70-letniej o niewielkiej amplitudzie. Analiza związków między $D_{3 \mathrm{~L}}$ a średnimi miesięcznymi i rocznymi sumami opadów nad Polską w latach 1951-2000 wykazała jednak brak istotnych korelacji między szeregami tych wielkości. Współczynnik korelacji $\mathrm{DG}_{3 \mathrm{~L}}$ ze średnią roczną sumą opadów na 5 polskich stacjach (Szczecin, Poznań, Wrocław, Warszawa, Kraków) jest równy $-0,18$ ( $p=0,215)$. Podobnej siły, słabe, nieistotne ujemne korelacje $(-0,19, p=0,186)$ zaznaczają się między sumami opadów letnich (czerwiec-sierpień) na obszarze Polski a wskaźnikiem $\mathrm{DG}_{3 \mathrm{~L}}$. Zdaje się to wskazywać, że związek sum opadów z NA THC jest na tyle słaby (jeśli w ogóle istnieje) i niestabilny, by nie wpływać na obniżenie przepływów w latach z dodatnimi wartościami wskaźnika $\mathrm{DG}_{3 \mathrm{~L}}$. 
Analiza związków wskaźnika $\mathrm{DG}_{3 \mathrm{~L}}$ ze średnią „obszarową” temperaturą powietrza nad Polską wykazuje w 50-leciu 1961-2010 istnienie niezbyt silnych, ale wysoce istotnych statystycznie związków z temperaturą roczną $(r=+0,50$, $p<0,001)$. We wszystkich miesiącach, za wyjątkiem grudnia, temperatura jest dodatnio skorelowana z $\mathrm{DG}_{3 \mathrm{~L}}$, przy czym na obszarze całego kraju statystycznie istotne korelacje temperatura $\mathrm{z} \mathrm{DG}_{3 \mathrm{~L}}$ wykazuje w kwietniu $(r=+0,60)$ oraz lipcu i sierpniu ( $r$ odpowiednio $+0,40 \mathrm{i}+0,46$ ). Przyczyną wzrostu temperatury nad Polską w dodatnich fazach wskaźnika NA THC jest statystycznie istotny wzrost częstości napływów ciepłego powietrza z SW i W (Marsz, 2015a).

Takiego rodzaju związki temperatury nad Polską ze wskaźnikiem DG $_{3 \mathrm{~L}}$ wskazują, że zmiany stanu termicznego Atlantyku Północnego mogą oddziaływać na przepływy rzek Polski głównie poprzez wpływ na rozmiary parowania w zlewniach. Podwyższona temperatura powietrza przez cały rok, a istotnie wyższa w środkowej części wiosny oraz w drugiej połowie lata w czasie dodatniej fazy NA THC przyczynia się do wzrostu ewapotranspiracji z powierzchni zlewni, powodując zmniejszenie odpływów. Wyjaśnia to występowanie ujemnych korelacji między intensywnością NA THC (wskaźnikiem $\mathrm{DG}_{3 \mathrm{~L}}$ ) a średnimi rocznymi przepływami rzek Polski.

Następna kwestia, na którą należy tu zwrócić uwagę, choć nie dotyczy bezpośrednio przepływu głównych rzek Polski, ale jest z nimi powiązana, to występowanie susz na obszarze Europy Środkowej. Jeśli dodatnim fazom AMO odpowiada przesunięcie antycyklonu Azorskiego na NE, Polska powinna znajdować się w warunkach częstszego oddziaływania układów wysokiego ciśnienia. Powinny wtedy zaistnieć warunki sprzyjające wystąpieniu suszy z uwagi zarówno na spadek liczby dni z opadem, jak i wzrost letniej temperatury powietrza. Autorzy nie dysponują bardziej precyzyjnymi danymi, np. szczegółowym kalendarzem susz obejmującym odpowiednio długi okres. $\mathrm{Na}$ podstawie danych z lat 1951-2011 przedstawionych przez H. Lorenc ${ }^{1}$, można zauważyć, że w okresie 1964-1988 (25 lat), czyli w ostatniej ujemnej fazie wskaźnika $D_{3 \mathrm{~L}}$ odnotowano cztery przypadki susz obejmujących ponad 75\% powierzchni kraju, w tym dwa przypadki suszy katastrofalnej (lata 1969 i 1982). W okresie 1989-2011 (23 lata), czyli dodatniej fazie przebiegu wskaźnika $\mathrm{DG}_{3 \mathrm{~L}}$ odnotowano 11 przypadków wystąpienia takich susz, w tym cztery przypadki susz katastrofalnych (lata 1992, 1994, 2006 i 2011). Sugeruje to, że częstość występowania susz nad Polską jest większa w okresie wzmożenia natężenia THC - w fazach „ciepłego” Atlantyku Północnego. Byłaby to zatem podobna sytuacja jak w Ameryce Północnej. Warto zauważyć, że ostatnia susza w roku 2015, z katastrofalnym obniżeniem przepływów rzek w Polsce nastąpiła w roku, w którym wskaźnik DG $_{3 \mathrm{~L}}$ osiągnął ekstremalną wartość (historyczne maksimum; 3,61) i była poprzedzona przez rok, w którym ten wskaźnik

\footnotetext{
${ }^{1}$ Prezentacja H. Lorenc na Seminarium PK GWP, 16.12.2011

(http://gwpl/data/uploads/prezentacje/ Susze i opady maksymalne w Polsce.pdf).
} 
osiągnął wyjątkowo dużą, wcześniej (1880-2013) nigdy nie notowaną wartość $(2,74)$. Czy rzeczywiście związki między intensywnością NA THC a wystąpieniem susz na obszarze Środkowej Europy występują, i na ile są one stabilne w czasie, powinny wyjaśnić badania oparte na pełniejszych szeregach danych.

\section{Piśmiennictwo}

Andronova N.G., Schlesinger M.E., 2000, Causes of global temperature changes during the 19th and 20th centuries, Geophysical Research Letters, 27, 14, s. 2137-2140.

Broecker W., 1991, The great ocean conveyor, Oceanography, 4, s. 79-89.

Carton J., 2011, Introduction to Atlantic Meridional Overturning Circulation (AMOC), Deep Sea Research II, 58, s. 1741-1743; doi: 10.1016/j.dsr2.2010.10.055.

Carton J.A., Cao X., Giese B.S., Da Silva A.M., 1996, Decadal and Interannual SST Variability in the Tropical Atlantic Ocean, Journal of Physical Oceanography, 26, 7, s. 1165-1175; doi: http://dx.doi.org/10.1175/1520-0485(1996)026<1165:DAISVI>2.0.CO;2.

Carton J., Cunningham S.A., Frajka-Williams E., Kwon Y-O., Marshall D.P., Msadek R., 2014, The Atlantic Overturning Circulation: More evidence of variability and links to climate, BAMS (Bulletin of American Meteorogical Society), 95, 8, ES63-ES66.

Chylek P., Klett J.D., Lesins G., Dubey M.K., Hengartner N., 2014, The Atlantic Multidecadal Oscillation as a dominant factor of oceanic influence on climate, Geophysical Research Letters, 41, s. 1689-1697; doi: 10.1002/2014GL059274.

Czaja A., Frankignoul C., 1999, Influence of the North Atlantic SST on the atmospheric circulation, Geophysical Research Letters, 26, 19, s. 2969-2972.

Delworth T.L., Greatbatch R.J., 2000, Multidecadal thermohaline circulation variability driven by atmospheric surface flux forcing, Journal of Climate, 13, 9, s. 1481-1495; doi: http://dx.doi.org/10.1175/1520-0442(2000)013<1481:MTCVDB>2.0.CO;2

Delworth T.L., Knutson T.R., 2000, Simulation of early 20th Century global warming, Science, 287, s. 2246-2250; doi: 10.1126/science.287.5461.2246.

Delworth T.L., Mann M.E., 2000, Observed and simulated multidecadal variability of the Northern Hemisphere, Climate Dynamics, 16, 9, s. 661-676; doi: 10.1007/s003820000075.

Enfield D.B., Mestas-Nuñez A.M., Trimble P.J., 2001, The Atlantic multidecadal oscillation and its relation to rainfall and river flows in the continental U.S., Geophysical Research Letters, 28, 10, s. 2077-2080.

Folland C.K., Knight J., Linderholm H.W., Fereday D., Ineson S., Hurrell J.W., 2009, The Summer North Atlantic Oscillation: Past, present, and future, Journal of Climate, 22, 5, s. 1082-1103; doi: http://dx.doi.org/10.1175/2008JCLI2459.1.

Frankignoul C., Friederichs P., Kestenare E., 2003, Influence of Atlantic SST anomalies on the atmospheric circulation in the Atlantic-European sector, Annals of Geophysics, 46, 1, s. 71-85.

Gray S.T., Graumlich L.J., Betancourt J.L., Pederson G.T., 2004, A tree-ring based reconstruction of the Atlantic Multidecadal Oscillation since 1567 A.D., Geophysical Research Letters, 31, L12205; doi: 10.1029/2004GL019932.

Grossmann I., Klotzbach P.J., 2009, A review of North Atlantic modes of natural variability and their driving mechanisms, Journal of Geophysical Research, 114, D24107 (1-14); doi: 10.1029/2009JD012728. 
Gulev S.K., Latif M., Keenlyside N., Park W., Kolterman K.P., 2013, North Atlantic Ocean control on surface heat flux on multidecadal timescales, Nature, 499, s. 464-467; doi: 10.1038/nature12268

Gutry-Korycka M., Boryczka J., 1990, Dtugookresowe zmiany elementów bilansu wodnego $w$ Polsce i zlewisku Battyku, Przegląd Geofizyczny, 35, 3-4, s. 19-32.

Hurrell J.W., 1995, Decadal trends in the North Atlantic Oscillation: regional temperatures and precipitation, Science, 269, 5224, s. 676-679.

Jones P.D., Jónsson T., Wheeler D., 1997, Extension to the North Atlantic Oscillation using early instrumental pressure observations from Gibraltar and south-west Iceland, International Journal of Climatology, 17, 13, s. 1433-1450.

Jokiel P., Kożuchowski K., 1989, Zmiany wybranych charakterystyk hydroklimatycznych Polski w bieżacym stuleciu, Dokumentacja Geograficzna, 6, IGiPZ PAN, Warszawa.

Kaczorowska Z., 1962, Opady w Polsce w przekroju wieloletnim: tendencje, okresowość oraz prawdopodobieństwo występowania niedoboru i nadmiaru opadów, Prace Geograficzne, IG PAN, 33, Warszawa.

Kerr R. A., 2000, A North Atlantic climate pacemaker for the centuries, Science, 288, 5473, s. 1984-1986.

Knight J.R., Allan R.J., Folland C.K., Vellinga M., Mann M.E., 2005, A signature of persistent natural thermohaline circulation cycles in observed climate, Geophysical Research Letters, 32, 20, L20708; doi: 10.1029/2005GL024233.

Knight J.R., Folland C.K., Scaife A.A., 2006, Climate impacts of the Atlantic Multidecadal Oscillation, Geophysical Research Letters, 33, L17706; doi: 10.1029/2006GL026242.

Kushnir Y., Seager R., Ting M., Naik N., Nakamura J., 2010, Mechanisms of Tropical Atlantic SST influence on North American precipitation variability, Journal of Climate, 23, 21, s. 5610-5628; doi: http://dx.doi.org/10.1175/2010JCLI3172.1

Latif M., Roeckner E., Botzet M., Esch M., Haak H., Hagemann S., Jungclaus J., Legutke S., Marsland S., Mikolajewicz U., Mitchell J., 2004, Reconstructing, monitoring, and predicting multidecadal-scale changes in the North Atlantic Thermohaline Circulation with sea surface temperature, Journal of Climate, 17, 7, s. 1605-1614; doi: http://dx.doi.org/10.1175/1520-0442(2004)017<1605:RMAPMC>2.0.CO;2.

Makowski J., Tomczak A., 2002, Stany wody Wisty w Toruniu w świetle pomiarów z ostatnich dwóch stuleci, Studia Societatis Scientiarum Toruniensis, Sectio C (Geographia et Geologia), 11, 1.

Marsz A.A., 2011, O zwiazkach między zmianami temperatury powierzchni Morza Sargassowego a zmianami temperatury powietrza na pótkuli pótnocnej (1880-2007), Landform Analysis, 15, s. 17-38.

Marsz A., 2015a, Cyrkulacja termohalinowa na Atlantyku Pótnocnym a temperatura powietrza w Polsce (1961-2010), Przegląd Geofizyczny, 60, 3-4, s. 109-131.

Marsz A., 2015b, Model zmian powierzchni lodów morskich Arktyki (1979-2013) - zmienne sterujace w modelu „minimalistycznym“ $i$ ich wymowa klimatyczna, Problemy Klimatologii Polarnej, 25, s. 249-334.

Marsz A.A., Styszyńska A., 2009, Oceanic control of the warming processes in the Arctica different point of view for the reasons of changes in the Arctic climate, Problemy Klimatologii Polarnej, 19, s. 7-31.

Nigam S., Guan B., Ruiz-Barradas A., 2011, Key role of the Atlantic Multidecadal Oscillation in 20th century drought and wet periods over the Great Plains, Geophysical Research Letters, 38, L16713; doi: 10.1029/2011GL048650.

Oglesby R.J., Feng S., Hu Q., Rowe C., 2011, Medieval drought in North America: The role of the Atlantic Multidecadal Oscillation, PAGES news, 19, 1, s. 18-20. 
Oglesby R., Feng S., Hu Q., Rowe C., 2012, The role of the Atlantic Multidecadal Oscillation on medieval drought in North America: Synthesizing results from proxy data and climate models, Global and Planetary Change, 84-85, s. 56-65. doi: 10.1016/j.gloplacha.2011.07.005.

Olejnik K., 1991, Przeptywy Warty w Poznaniu 1822-1988, Fundacja Warta, Poznań.

Piętka I., 2009, Wieloletnia zmienność wiosennego odptywu rzek polskich, Prace i Studia Geograficzne UW, 43, s. 81-95.

Pociask-Karteczka J., 2006, River hydrology and the North Atlantic Oscillation: A general review, AMBIO: A Journal of the Human Environment 35, 6, s. 312-314; doi: http://dx.doi.org/10.1579/05-S-114.1.

Pociask-Karteczka J., Limanówka D., Nieckarz Z., 2002-2003, Wpływ oscylacji pótnocnoatlantyckiej na przeptywy rzek karpackich (1951-2000), Folia Geographica, ser. Geographica Physica, 33-34, s. 89-104.

Pohlmann H., Sienz F., Latif M., 2006, Influence of the Multidecadal Atlantic Meridional Overturning circulation variability on European climate, Journal of Climate, 19 (23 - Special Section: Climate Variability and Predictability Study (CLIVAR): Atlantic Climate Predictability), s. 6062-6067; doi: http://dx.doi.org/10.1175/JCLI3941.1.

Schlesinger M.E., Ramankutty N., 1994, An oscillation in the global climate system of period 65-70 years, Nature, 367, s. 723-726.

Screen J.A., 2013, Influence of Arctic sea ice on European summer precipitation, Environmental Research Letters, 8; 044015; s. 1-9; doi: 10.1088/1748-9326/8/4/044015.

Smith T.M., Reynolds R.W., Peterson T.C., Lawrimore J., 2008, Improvements to NOAA's historical merged land-ocean surface temperature analysis (1880-2006), Journal of Climate, 21 (10), s. 2283-2296; doi: http://dx.doi.org/10.1175/2007JCLI2100.1.

Styszyńska A., Tamulewicz J., 2005, Warta river discharges in Poznań and atmospheric circulation in the North Atlantic region, Quaestiones Geographicae, 23, s. 63-81.

Sutton R.T., Hodson D.L.R., 2005, Atlantic Ocean forcing of North American and European summer climate, Science, 290, s. 2133-2137.

Sutton R.T., Hodson D.L.R., 2007, Climate response to basin-scale warming and cooling of the North Atlantic Ocean, Journal of Climate, 20, 5, s. 891-907; doi: http://dx.doi.org/10.1175/JCLI4038.1.

Sutton R.T., Dong B., 2012, Atlantic Ocean influence on a shift in European climate in the 1990s, Nature Geoscience, 5, s. 788-792; doi: 10.1038/ngeo1595.

Ting M., Kushnir Y., Seager R., Li C., 2011, Robust features of Atlantic multi-decadal variability and its climate impacts, Geophysical Research Letters, 38, L17705; doi: 10.1029/2011GL048712.

Vimont D.J., Kossin J.P., 2007, The Atlantic Meridional Mode and hurricane activity, Geophysical Research Letters, 34, L07709; doi: 10.1029/2007GL029683.

Vorosmarty C.J., Fekete B.M., Tucker B.A., 1998, Global River Discharge, 1807-1991, Version 1.1 (RivDIS). Data set. Available on-line [http://www.daac.ornl.gov] from Oak Ridge National Laboratory Distributed Active Archive Center, Oak Ridge, Tennessee, U.S.A.; doi: 10.3334/ORNLDAAC/199.

Willems P., 2013, Multidecadal oscillatory behaviour of rainfall extremes in Europe, Climatic Change, 120, s. 931-944; doi: 10.1007/s10584-013-0837-x.

Wrzesiński D., 2009, Tendencje zmian przeptywu rzek Polski w drugiej potowie XX w., Badania Fizjograficzne nad Polską Zachodnią, Ser. A., 60, s. 147-162; doi: 10.2478/v10116-009-0025-X.

Wrzesiński D., 2011, Regional differences in the influences of the North Atlantic Oscillation on seasonal river runoff in Poland, Quaestiones Geographicae, 30, 3, s. 127-236. 
Wrzesiński D., Paluszkiewicz R., 2011, Spatial differences in the impact of the North Atlantic Oscillation on the flow of rivers in Europe, Hydrology Research, 42, 1, s. 30-39, doi: 10.2166/nh.2010.077.

Zhang R., Delworth T.L., Held I.M., 2007, Can the Atlantic Ocean drive the observed multidecadal variability in Northern Hemisphere mean temperature?, Geophysical Research Letters, 34, L02709, doi: 10.1029/2006GL028683.

Zhang L., Wang C., 2013, Multidecadal North Atlantic sea surface temperature and Atlantic meridional overturning circulation variability in CMIP5 historical simulations, Journal of Geophysical Research: Oceans, 118, 10, s. 5772-5791, doi: 10.1002/jgrc.20390.

Zveryaev I.I., 2009, Interdecadal changes in the links between European precipitation and atmospheric circulation during boreal spring and fall, Tellus, 61 A, s. 50-56.

[Wpłynęło: czerwiec; poprawiono: sierpień 2016 r.]

\section{ANDRZEJ A. MARSZ, ANNA STYSZYŃSKA, WIESŁAWA E. KRAWCZYK}

\section{LONG-TERM FLUCTUATIONS OF ANNUAL DISCHARGES OF THE MAIN RIVERS IN POLAND AND THEIR ASSOCIATION WITH THE NORTHERN ATLANTIC THERMOHALINE CIRCULATION}

In this paper it is the associations between mean annual discharges of the main rivers in Poland and the surface component of the Northern Atlantic Thermohaline Circulation (NA THC) that are analysed. Relevant data derived from hydrometric profiles on the country's main rivers, i.e. the Vistula at Tczew (years 1901-2015), the River Bug at Wyszków (1921-2015), the Oder at Gozdowice (1901-2015) and the Warta in Poznań (1822-2015). Use was also made of the time series for annual discharges of the Vistula at Toruń (1822-2000). Results show that, despite marked inter-annual variability to discharges in two periods (1921-2015 and 1822-2000), there is a common rhythm to long-term discharge fluctuations (Table 1, Figure 1), with consecutive increases and decreases in annual discharges. The analysis shows that the changeability of annual discharges and variability in the NA THC are characterised by weak, but highly statistically significant associations (Table 2). In periods in which the NA THC intensifies (as indicated by the $\mathrm{DG}_{3 \mathrm{~L}}$ index), river discharges are found to decrease; whereas a fall in the intensity of NA THC is associated with an increase in the intensity of river discharges (Figs. 2, 3 and 4). While small, these differences do assume a high level of statistical significance (Fig. 4). Figs. 2, 3 and 4 also show how the occurrence of positive values for the NA THC $\left(+\mathrm{DG}_{3 \mathrm{~L}}\right)$ sees the degree of variability of annual discharges reduced in relation to that present when values for the NA THC are negative $\left(-\mathrm{DG}_{3 \mathrm{~L}}\right)$. Given that the variability characterising the $\mathrm{DG}_{3 \mathrm{~L}}$ index (NA THC) displays multi-decadal oscillations (Fig. 6), it is not surprising that such oscillations also occur where discharges from Poland's main rivers are concerned. The differences between discharges occurring in the positive and negative phases of the NA THC $\left(+\mathrm{DG}_{3 \mathrm{~L}}\right.$ and $-\mathrm{DG}_{3 \mathrm{~L}}$ amount to around $10 \%$. The main reason for such an association is that variability in the NA THC (with which changes in the thermal state of the Northern Atlantic are connected) is what is known to regulate some aspects of atmospheric circulation. As a result, in the circum- 
stances of positive values for the $\mathrm{DG}_{3 \mathrm{~L}}$ index, mean annual air temperature in Poland is higher (and in April, July and August significantly higher) than at times when a negative $\mathrm{DG}_{3 \mathrm{~L}}$ index is present. When positive values for the $\mathrm{DG}_{3 \mathrm{~L}}$ index arise, there are greater losses due to evaporation (or evapotranspiration) in the river catchments in Poland, with the result that discharges are reduced. No statistically significant relationships were found between the NA THC and precipitation in Poland. However, while there are no statistically significant relationships between mean annual discharges from the rivers in Poland and the AMO index, associations between discharges and the $\mathrm{DG}_{3 \mathrm{~L}}$ index characterising the intensity of the thermohaline circulation in the Northern Atlantic - do achieve statistical significance. The results obtained suggest that the relationship between the intensity of the NA THC and the occurrence of droughts in Poland should be investigated. 